\title{
The Association Between Three Adipocytokines (Adiponectin, Resistin and Visfatin) And Thyroid Status in Patients With Type 2 Diabetes Mellitus and Autoimmune Thyroiditis
}

\section{Štefan SOTAK ${ }^{1}$, Zbynek SCHRONER ${ }^{2}$, Ivica LAZÚROVÁ ${ }^{1}$, Marek FELŠőCI $^{3}$, Ivana JOCHMANOVÁ ${ }^{1}$, Darina PETRÁŠOVÁ ${ }^{4}$, Izabela BERTKOVÁ ${ }^{5}$, Miriam MITNÍKOVÁ $^{6}$, Božena NOVÁKOVÁ ${ }^{1}$, Hedviga WAGNEROVÁ ${ }^{1}$, Ol'ga BOBELOVÁ $^{1}$}

${ }^{1} \mathrm{I}^{\text {st }}$ Department of Internal Medicine, Louis Pasteur University Hospital and Pavol Jozef Šafárik University - Faculty of Medicine, Košice, Slovak Republic, ${ }^{2} \mathrm{IV}^{\text {th }}$ Department of Internal Medicine, Louis Pasteur University Hospital, Department of Diabetology, Slovak Medical University, Košice, Slovak Republic, ${ }^{3} \mathrm{I}^{\text {st }}$ Department of Internal Medicine, Louis Pasteur University Hospital, Košice, Slovak Republic, ${ }^{4}$ Laboratory of Research Bio-Models, Pavol Jozef Šafárik University - Faculty of Medicine, Košice, Slovak Republic, ${ }^{5}$ Department of Experimental Medicine, Pavol Jozef Šafárik University - Faculty of Medicine, Košice, Slovak Republic, ${ }^{6}$ Department of Laboratory Medicine, Louis Pasteur University Hospital, Košice, Slovak Republic

Received April 12, 2021

Accepted September 10, 2021

Epub Ahead of Print October 30, 2021

\section{Summary}

Autoimmune thyroiditis (AIT) and type 2 diabetes mellitus (DM2) are the most common endocrinological diseases worldwide. Relation between these diseases explains several hypotheses. One of them is influence of some adipocytokines. This study evaluated association between three adipocytokines (adiponectin, resistin and visfatin) and thyroid and glycid status in patients with DM2 and AIT compared to the control group (CG). The group consisted of four subgroups: patients with DM2 without thyreopathies, patients with AIT on substitution therapy without diabetes and prediabetes, patients with DM2 and AIT on substitution therapy and healthy subjects as the CG. We investigated parameters of thyroid and glucose metabolism and serum levels of three adipocytokines. The mean level of resistin in the group of patients with diabetes and thyroiditis was significantly higher than in patients with thyroiditis without diabetes and than in the CG. We found a weak negative correlation between visfatin and fasting glucose levels in patients with thyroiditis without diabetes. We detected a weak negative correlation between resistin and glycated hemoglobin and a weak negative correlation between visfatin and thyroid gland volume in patients with diabetes without thyroiditis. In the CG we determined a weak positive correlation between visfatin and free thyroxin. Our results are consistent with several studies, which confirmed association between AIT and adipocytokines.

\section{Key words}

Type 2 diabetes mellitus - Autoimmune thyroiditis • Adipocytokines • Adiponectin • Visfatin • Resistin

\section{Corresponding author}

Štefan Sotak, I ${ }^{\text {st }}$ Department of Internal Medicine, Louis Pasteur University Hospital and Pavol Jozef Šafárik University - Faculty of Mediciny, Tr. SNP 1, 04011 Košice, Slovak Republic. E-mail: stefan.sotak@unlp.sk

\section{Introduction}

Autoimmune thyroiditis (AIT) and type 2 diabetes mellitus (DM2) are two most common endocrine diseases encountered in clinical practice (Schroner et al. 2008). The relationship between AIT and DM1 has been studied in more detail, but there is also a link between DM2 and thyroid diseases. The cause of the increased incidence of AIT in DM2 is not fully known. Genetic factors are investigated, e.g. deiodinase (deiodinase

PHYSIOLOGICAL RESEARCH • ISSN 1802-9973 (online) - an open access article under the CC BY-NC-ND 4.0 license (c) 2021 Institute of Physiology of the Czech Academy of Sciences, Prague, Czech Republic 
type II - Thr92Ala) or vitamin D receptor gene polymorphisms. The effect of infections is also under review. Furthermore, a lack of iodine in the diet may be also involved. Decreased iodine intake is a risk factor for goiter, which, in turn, is a risk factor for AIT (Schroner et al. 2008). Vitamin D-poor diet may be another causative factor for AIT development in patients with DM2. Obesity, which is common in DM2, leads to a decrease in the level of this hormone. Vitamin D deficiency has several negative effects on the human organism, one of them being increase in the proinflammatory activity and a decrease of antiinflammatory activity, which can be risks factors for developing autoimmune inflammation (Kresser 2019).

Another hypothesis presumes the effects of some adipocytokines (adipokines) in the AIT etiopathogenesis in DM2. In the present study we focus at three of them: adiponectin, resistin, and visfatin. Thyroid hormones (TH) are involved in the regulation of body metabolism. Their effects include the stimulation of resting metabolic rate, increase in energy expenditure, modulation of responsiveness to catecholamines, and thermogenesis in adipose tissue. Disturbances in thyroid function lead to changes in body weight, muscle mass, and fat tissue. Thyroid-stimulating hormone (TSH) receptors have been found in the adipose tissues, indicating that they play a role in the regulation of the adipocytokines which are involved in the regulation of energy balance (Cinar and Gurlek 2013). As patients with thyrotoxicosis lose body fat and patients with myxedema regain it, one can suppose that the production of these adipokines will be suppressed in hyperthyroidism and potentiated in hypothyroidism. However, many studies contradict this precondition, which is explained by several factors (Cinar and Gurlek 2013). The sympathetic nervous system and $\mathrm{TH}$ regulate a number of metabolic processes in a complementary fashion (Mullur et al. 2014). The role of $\mathrm{TH}$ within the central nervous system is evolving and now includes alterations in neuroendocrine peptides related to energy intake, nongenomic actions of $\mathrm{TH}$ within the hypothalamus, the action of decarboxylated and deiodinated analogs of $\mathrm{TH}$ and also several adipocytokines (Mullur et al. 2014). Adipocytokines are proteins that are formed primarily in adipocytes, but also in endothelial cells, fibroblasts, leukocytes, and macrophages. These cytokines affect numerous functions in the organism. Their exact roles are still unclear (Misra and Vikram 2003) and need further research.
We did not choose adiponectin, resistin and visfatin as a subject of our research because we assumed their closest relationship to glucose and thyroid metabolism, but because there is probably the largest amount of data on these three adipokines in the current literature.

The aim of the present work was to determine the association between three adipocytokines (adiponectin, resistin, and visfatin) and thyroid and glycid status in patients with DM2 and AIT compared to the control group (CG).

\section{Methods}

This study included a total number of 181 patients and 43 controls. Patients were divided into three groups.

The first group consisted of 80 patients (56 males and 24 females) with the established diagnosis of DM2 and median age of 62 (range 41-65) years. All diabetic subjects were consecutively recruited from the $1^{\text {st }}$ Department of Internal Medicine of Louis Pasteur University Hospital in Košice, Slovakia and its outpatient office for diabetology from January 2013 to November 2020. Patients with previous history of the thyroid disease as well as other endocrine disease were primarily excluded from the study. The second group included 54 patients ( 7 males and 47 females) with thyroid disease, who have had established diagnosis of AIT in hypothyroid stadium; median age in this group was 61 (range 19-65) years. Patients with previous history of prediabetes or diabetes were excluded from this arm of the study. The third group, in which the median age was 63 (range 27-65) years, comprised 47 patients (7 males and 40 females) with both established diagnosis of DM2 and AIT in the stadium of hypothyreosis. Subjects in second and third group were also recruited from the $1^{\text {st }}$ Department of Internal Medicine of the Louis Pasteur University Hospital in Košice, Slovakia and its outpatient office for endocrinology during the same period of time as those in the first group. CG consisted of 43 subjects (18 males and 25 females) of median age 53.5 (range 20-65) years. DM, thyroid disease or any other endocrine diseases have been carefully excluded in all subjects enrolled in the CG. We also excluded patients treated by glucocorticoids, with chronic pancreatitis, with anti-GAD antibodies positivity, and patients with history of cancer. All subjects were younger than 65 years. The study was approved by the Ethics committee of the Louis 
Pasteur University Hospital in Košice, Slovak Republic (in accordance with the ethical standards laid down in the 1964 Declaration of Helsinki) and written informed consent for the study was obligatory for all of the participants.

All patients and controls underwent clinical and laboratory evaluation. Basic anthropometric, thyroid, and metabolic parameters as well as the morphology of thyroid gland were assessed in all patients and in all control subjects. The following variables were assessed: age, gender, height, weight, body mass index (BMI), waistline, and volume of thyroid gland. For the laboratory assessment, fasting blood samples were collected from the patients and controls to estimate three adipocytokines (adiponectin, resistin, visfatin), free thyroxine ( $\left.\mathrm{fT}_{4}\right), \mathrm{TSH}$ serum levels as well as serum concentrations of autoantibodies to thyroglobulin (aTG) and thyroid peroxidase (aTPO). Additionally, fasting glycaemia and glycated haemoglobin $\left(\mathrm{HbA}_{1 \mathrm{c}}\right)$ levels were assessed among parameters of glucose metabolism. Photometric colorimetry was used for the examination of glycaemia, electrochemiluminescent immunochemistry for the evaluation of $\mathrm{HbA}_{1 \mathrm{c}}, \mathrm{fT}_{4}, \mathrm{TSH}, \mathrm{aTG}$, and aTPO antibodies and ELISA method for adipocytokines, respectively. For the assessment of $\mathrm{HbA}_{1 \mathrm{c}}$ we used The Diabetes Control and Complications Trial standard with normal values $<6.5 \%$. BMI was calculated as weight $(\mathrm{kg})$ divided by the square of height $\left(\mathrm{m}^{2}\right)$. Volume, morphology, and patomorphology of thyroid gland were assessed using Esaote Technos MPx ultrasound and performed by the same ultrasonographer and calculated by the formula

$\left(a_{L} \times b_{L} \times c_{L} \times \pi / 6\right)+\left(a_{R} \times b_{R} \times c_{R} \times \pi / 6\right)$,

where

$\mathrm{a}_{\mathrm{L}}$ - height of left thyroid lobe in $\mathrm{mm}$,

$\mathrm{b}_{\mathrm{L}}$ - width of left thyroid lobe in $\mathrm{mm}$,

$\mathrm{c}_{\mathrm{L}}$ - length of left thyroid lobe in $\mathrm{mm}$,

$a_{R}$ - height of right thyroid lobe in $\mathrm{mm}$,

$b_{R}-$ width of right thyroid lobe in $\mathrm{mm}$,

$\mathrm{c}_{\mathrm{R}}-$ length of right thyroid lobe in $\mathrm{mm}$.

Diagnostic criteria for primary hypothyroidism included: TSH serum concentrations $>4.2 \mathrm{mIU} / \mathrm{ml}$ and low or normal levels of fT4. Diagnostic criteria for AIT were: positive ultrasonography (USG) image (diffuse homogenous or blotchy hypoechogenicity of thyroid tissue) and presence of aTG antibodies (serum levels above $115 \mathrm{kIU} / \mathrm{l}$ ) and/or aTPO antibodies (serum levels above $34 \mathrm{kIU} / \mathrm{l})$.

\section{Statistical analysis}

Continuous variables are presented as median and range, categorical variables are expressed as frequency counts and percentages. Comparisons of the central tendencies of the different groups were performed using unpaired two-tailed Student t-test or Mann-Whitney $\mathrm{U}$ test for non-normally distributed parameters. A simple linear regression analysis and a correlation analysis with the determination of the Pearson's (r) or Spearman's ( $\rho$ ) correlation coefficient were used as appropriate to determine associations between the variables. The differences between continuous parameters divided into more than two subgroups were calculated by one-way ANOVA. P-value of $<0.05$ was considered statistically significant. All numerical values are rounded to 2 decimal places. Statistical analysis was performed using IBM SPSS Statistics Premium Faculty Pack (IBM, USA).

\section{Results}

Mean values of anthropometric, glycemic and thyroid parameters of patients of all 3 groups and CG are shown in the Table 1 . There was no difference in the mean age between groups. As shown in the Table 2, the levels of resistin in the group of patients with DM2 and AIT were significantly higher than in patients with AIT without DM2 (8.90 [range 1.94-52.45] vs. 5.75 [range 2.28-49.58] ng/ml, respectively, $\mathrm{p}<0.01)$ and than in $\mathrm{CG}$ 8.90 [range 1.94-52.45] vs. 5.59 [range 0.0-49.42] $\mathrm{ng} / \mathrm{ml}$, respectively, $\mathrm{p}<0.01)$. We also detected correlation between individual adipocytokines and the values of the parameters examined by us in all four investigated groups (Tables 3, 4, 5, 6). We detected a weak negative correlation between resistin and $\mathrm{HbA}_{1 \mathrm{C}}$ in patients with DM2 without AIT $(\rho=-0.26, p=0.02$; Table 3). Surprisingly, we observed visfatin to be weakly negatively correlated with the volume of thyroid gland in patients with DM2 without thyroid disease $(\rho=-0.35$, $\mathrm{p}=0.001$; Table 3 ). We also detected a weak negative correlation between visfatin and fasting glycaemia levels ( $\rho=-0.39, p=0.003$; Table 4 ) in the group of patients with AIT without DM2. In CG we determined a weak positive correlation between visfatin and $\mathrm{fT}_{4}(\rho=0.36, \mathrm{p}=0.02$; Table 6). No correlations between studied adipocytokines and other evaluated parameters were observed in patients with concomitant DM2 and AIT (Table 5). 
Table 1. Glucose and thyroid metabolism characteristics in individual groups

\begin{tabular}{|c|c|c|c|c|}
\hline & $\begin{array}{l}\text { DM2 without AIT } \\
(\mathbf{n}=\mathbf{8 0})\end{array}$ & $\begin{array}{l}\text { AIT without DM2 } \\
\qquad(\mathrm{n}=54)\end{array}$ & $\begin{array}{c}\mathrm{DM} 2+\mathrm{AIT} \\
(\mathrm{n}=47)\end{array}$ & $\begin{array}{c}C G \\
(n=43)\end{array}$ \\
\hline age (years)* & $53.5(20-65)$ & $61(19-65)$ & $63(27-65)$ & $62(41-65)$ \\
\hline $\begin{array}{l}\text { volume of thyroid gland } \\
(\mathrm{ml})^{*}\end{array}$ & $13.61(7.5-29.2)$ & $10.89(4.57-38.8)$ & $8.42(4.2-17.8)$ & $11.8(4.3-21.62)$ \\
\hline$f T_{4}(\mathrm{pmol} / \mathrm{l}) *$ & $13.43(7.69-34.86)$ & $14.22(3.2-27.8)$ & $14.25(5.23-20.55)$ & $14.71(5.6-23.99)$ \\
\hline TSH $(m I U / l) *$ & $2.22(0.018-14.03)$ & $2.86(0.36-129.7)$ & $3.41(0.28-35.27)$ & $1.34(0.25-6.16)$ \\
\hline $\operatorname{anti-Tg}(k I U / l) *$ & $11.52(6.95-271.7)$ & $13.29(5.0-452)$ & $\begin{array}{c}17.07 \\
(10.0-3256.7)\end{array}$ & $11.87(10.0-251.4)$ \\
\hline anti-TPO (kIU/l)* & $10.97(5.0-53.26)$ & $20.08(5.0-2734.3)$ & $34.25(5.0-379.0)$ & $8.19(5.0-31.37)$ \\
\hline Gly $(\mathrm{mmol} / \mathrm{ll})^{*}$ & $6.75(3.8-53.26)$ & $4.85(3.9-6.9)$ & $7.2(3.9-14.8)$ & $4.9(2.8-7.1)$ \\
\hline$H b A_{l C}(\%) *$ & $7.2(3.5-16.37)$ & $5.15(4.1-59.0)$ & $7.0(4.2-14.1)$ & $5.3(3.0-6.5)$ \\
\hline$B M I\left(k g / m^{2}\right)^{*}$ & $29.0(18.3-51.0)$ & $25.5(20.3-46.9)$ & $27.8(20.7-40.9)$ & $23.8(12.0-40.15)$ \\
\hline waist $(\mathrm{cm})^{*}$ & $97.0(70.0-140.0)$ & $84(65.0-123.0)$ & $86.0(70.0-127.0)$ & $80(55.0-127.0)$ \\
\hline
\end{tabular}

* expressed as median (range)

Table 2. Median values of examined adipocytokines in individual groups

\begin{tabular}{lcccc}
\hline & DM2 $(\mathbf{n}=\mathbf{8 0})$ & AIT $(\mathbf{n}=\mathbf{5 4})$ & DM2 + AIT $(\mathbf{n}=\mathbf{4 7})$ & CG $(\mathbf{n}=\mathbf{4 3})$ \\
\hline adiponectin $(\mu \mathrm{g} / \mathrm{ml}) *$ & $8.63(1.58-51.53)$ & $11.36(0.53-40.61)$ & $10.33(4.5-29.9)$ & $7.94(2.28-34.33)$ \\
resistin $(\mathrm{ng} / \mathrm{ml}) *$ & $8.89(1.32-48.37)$ & $5.75(2.28-49.58)$ & $8.90(1.94-52.45)$ & $5.86(0.0-49.42)$ \\
visfatin $(\mathrm{ng} / \mathrm{ml}) *$ & $3.11(0.0-12.07)$ & $3.38(0.014-10.79)$ & $3.41(0.22-9.02)$ & $4.64(0.074-10.57)$ \\
\hline
\end{tabular}

* expressed as median (range)

Table 3. Correlations between individual adipokines and parameters of glucose and thyroid metabolism in patients with DM2 without thyroid disease

\begin{tabular}{lccc}
\hline & adiponectin & resistin & visfatin \\
\hline volume of thyroid gland $(\mathrm{ml})^{*}$ & $\mathrm{NS}$ & $\mathrm{NS}$ & $\rho=-0.35, \mathrm{p}=0.001$ \\
$f T_{4}(\mathrm{pmol} / \mathrm{l})^{*}$ & $\mathrm{NS}$ & $\mathrm{NS}$ & $\mathrm{NS}$ \\
TSH $(\mathrm{mIU} / \mathrm{ll})^{*}$ & $\mathrm{NS}$ & $\mathrm{NS}$ & $\mathrm{NS}$ \\
anti-Tg $(\mathrm{klU} / \mathrm{l})^{*}$ & $\mathrm{NS}$ & $\mathrm{NS}$ & $\mathrm{NS}$ \\
anti-TPO $(\mathrm{kIU} / \mathrm{l})^{*}$ & $\mathrm{NS}$ & $\mathrm{NS}$ & $\mathrm{NS}$ \\
Gly $(\mathrm{mmol} / \mathrm{l})^{*}$ & $\mathrm{NS}$ & $\mathrm{NS}$ & $\mathrm{NS}$ \\
HbA $A_{l \mathrm{C}}(\%)^{*}$ & $\mathrm{NS}$ & $\rho=-0.26, \mathrm{p}=0.02$ & $\mathrm{NS}$ \\
BMI $\left(\mathrm{kg} / \mathrm{m}^{2}\right)^{*}$ & $\mathrm{NS}$ & $\mathrm{NS}$ & $\mathrm{NS}$ \\
waist $(\mathrm{cm})^{*}$ & $\mathrm{NS}$ & $\mathrm{NS}$ & $\rho=-0.26, \mathrm{p}=0.02$ \\
\hline
\end{tabular}

* expressed as median (range)

\section{Discussion}

As mentioned above, several authors assume that hypothyroidism potentiates the production of adipocytokines.

Our results given in Table 2, which, although of statistically low significance, found gradually increasing median adiponectin concentration in CG vs. diabetics without AIT vs. diabetics with AIT vs. patients with AIT without DM2.

Resistin increased in the group of patients with AIT without DM2 and CG vs. diabetics with or without AIT. 
In contrast, the median concentration of visfatin was highest in $\mathrm{CG}$ and decreased in terms of CG vs. diabetics with AIT vs. patients with AIT without DM2 vs. diabetics without AIT.

\section{Adiponectin}

Adiponectin has many important roles, including increasing insulin sensitivity in muscles and liver, lowering plasma glucose levels, and protecting blood vessels from developing atherogenic changes. Its level is reduced in DM2. Adiponectin and $\mathrm{TH}$ involve in several biological processes, e.g. they reduce the amount of fat by increasing thermogenesis and lipid oxidation (Ahima et al. 2006). It is considered that adiponectin may affect the production of $\mathrm{TH}$ through interaction with the $\mathrm{gClq}$ receptor found in the mitochondria of thyroid cells (Fernández-Real et al. 2003). On the other hand, the partial inhibitory effect of triiodothyronine on the adiponectin mRNA expression process in white adipose tissue has been demonstrated relatively recently (Cabanelas et al. 2010). Iglesias et al. (2003) described lower levels of adiponectin in hypothyroidism (mainly patients with Hashimoto's thyroiditis). In contrast, Santini et al. (2004), Altinova et al. (2006), Iglesias and Díez (2007), Siemińska et al. (2010), Kaplan et al. (2012), Yldiz et al. (2013) as well as our study found no difference between hypothyroid group and CG (Table 2). $\mathrm{HbA}_{1 \mathrm{c}}$ as an indicator of glycemic control showed a negative correlation with serum adiponectin. Low adiponectin concentration may predict the development of diabetes and may have an important role in the pathogenesis of diabetes. Most of studies confirm it (Lindsay et al. 2002, Spranger et al. 2003, FernándezReal et al. 2004, Goodarzi et al. 2007). However some studies came to opposite conclusion (Owecki et al. 2008).

We detected a negative correlation between adiponectin and $\mathrm{HbA}_{1 \mathrm{c}}$ in all four groups, but the correlation was not statistically significant (Table 6).

\section{Resistin}

Resistin is an adipocytokine hormone very commonly associated with DM2, obesity, and insulin resistance (Stumvoll and Häring 2002). Its level decreases with age, in men is higher than in women (Nogueraz et al. 2003). Its importance in these pathological conditions, in a positive or negative sense, is currently much debated. It is certain that it increases the level of "bad" LDL-cholesterol and prevents its dissolution in the liver (Stumvoll and Häring 2002).

Several studies show no association between levels of resistin and TH (Siemińska et al. 2010, Kaplan et al. 2012) as well as ours (Table 4). In hypothyroidism, according to one study, unchanged levels were found (Krassar et al. 2006) as well as in ours, according to another, they were reduced (Iglesias and Díez 2007). On the other hand, resistin, by increasing the activity of the enzyme iodothyronine deiodinase type $\mathrm{I}$, can increase $\mathrm{fT}_{4}$ (Ziora et al. 2011). It was not clarified yet, if serum levels of resistin are normal or lower in patients with DM2. Some studies declares there is not a significant difference between resistin levels in diabetics and non-diabetics, others confirm its increased levels in diabetics. We confirmed it, but only in diabetics with AIT (Table 2). According to several studies resistin correlates with $\mathrm{HbA}_{1 \mathrm{C}}$ in diabetics, but not in non-diabetics. Other studies declares no correlation nor in diabetics neither in non-diabetics. Our study confirmed this correlation (Table 3).

Table 4. Correlations between individual adipokines and parameters of glucose and thyroid metabolism in patients with AIT without impaired glucose metabolism

\begin{tabular}{lccc}
\hline & adiponectin & resistin & visfatin \\
\hline volume of thyroid gland $(\mathrm{mll})^{*}$ & $\mathrm{NS}$ & $\mathrm{NS}$ & $\mathrm{NS}$ \\
$f T_{4}(\mathrm{pmol} / \mathrm{l})^{*}$ & $\mathrm{NS}$ & $\mathrm{NS}$ & $\mathrm{NS}$ \\
$T S H(\mathrm{mIU} / \mathrm{l})^{*}$ & $\mathrm{NS}$ & $\mathrm{NS}$ & $\mathrm{NS}$ \\
anti-Tg $(\mathrm{kIU} / \mathrm{l})^{*}$ & $\mathrm{NS}$ & $\mathrm{NS}$ & $\mathrm{NS}$ \\
anti-TPO $(\mathrm{kIU} / \mathrm{l})^{*}$ & $\mathrm{NS}$ & $\mathrm{NS}$ & $\mathrm{NS}$ \\
Gly $(\mathrm{mmol} / \mathrm{l})^{*}$ & $\mathrm{NS}$ & $\mathrm{NS}$ & $\rho=-0.39, \mathrm{p}=0.003$ \\
$H b A_{l C}(\%)^{*}$ & $\mathrm{NS}$ & $\mathrm{NS}$ & $\mathrm{NS}$ \\
BMI $\left(\mathrm{kg} / \mathrm{m}^{2}\right)^{*}$ & $\mathrm{NS}$ & $\mathrm{NS}$ & $\mathrm{NS}$ \\
waist $(\mathrm{cm})^{*}$ & $\mathrm{NS}$ & $\mathrm{NS}$ & $\mathrm{NS}$ \\
\hline
\end{tabular}

* expressed as median (range) 
Table 5. Correlations between individual adipokines and parameters of glucose and thyroid metabolism in patients with DM2 and AIT

\begin{tabular}{lccc}
\hline & adiponectin & resistin & visfatin \\
\hline $\begin{array}{l}\text { volume of thyroid gland } \\
(\mathrm{ml})^{*}\end{array}$ & $\mathrm{NS}$ & $\mathrm{NS}$ & $\mathrm{NS}$ \\
$f T_{4}(\mathrm{pmol} / \mathrm{l})^{*}$ & $\mathrm{NS}$ & $\mathrm{NS}$ & $\mathrm{NS}$ \\
$T S H(\mathrm{mIU} / \mathrm{l})^{*}$ & $\mathrm{NS}$ & $\mathrm{NS}$ & $\mathrm{NS}$ \\
anti-Tg $(\mathrm{kIU} / \mathrm{l})^{*}$ & $\mathrm{NS}$ & $\mathrm{NS}$ & $\mathrm{NS}$ \\
anti-TPO $(\mathrm{kIU} / \mathrm{l})^{*}$ & $\mathrm{NS}$ & $\mathrm{NS}$ & $\mathrm{NS}$ \\
Gly $(\mathrm{mmol} / \mathrm{l})^{*}$ & $\mathrm{NS}$ & $\mathrm{NS}$ & $\mathrm{NS}$ \\
$H b A_{l C}(\%)^{*}$ & $\mathrm{NS}$ & $\mathrm{NS}$ & $\mathrm{NS}$ \\
BMI $\left(\mathrm{kg} / \mathrm{m}^{2}\right)^{*}$ & $\mathrm{NS}$ & $\mathrm{NS}$ & $\mathrm{NS}$ \\
waist $(\mathrm{cm})^{*}$ & $\mathrm{NS}$ & & $\mathrm{NS}$ \\
\hline
\end{tabular}

* expressed as median (range)

Table 6. Correlations between individual adipokines and parameters of glucose and thyroid metabolism in CG

\begin{tabular}{lccc}
\hline & adiponectin & resistin & visfatin \\
\hline $\begin{array}{l}\text { volume of thyroid gland } \\
(\mathrm{mll})^{*}\end{array}$ & $\mathrm{NS}$ & $\mathrm{NS}$ & $\mathrm{NS}$ \\
$f T_{4}($ pmol/l)* & $\mathrm{NS}$ & $\mathrm{NS}$ & $\rho=0.36, \mathrm{p}=0.02$ \\
$T S H(m I U / l)^{*}$ & $\mathrm{NS}$ & $\mathrm{NS}$ & $\mathrm{NS}$ \\
anti-Tg $(\mathrm{kIU} / \mathrm{ll})^{*}$ & $\mathrm{NS}$ & $\mathrm{NS}$ & $\mathrm{NS}$ \\
anti-TPO $(\mathrm{kIU} / \mathrm{l})^{*}$ & $\mathrm{NS}$ & $\mathrm{NS}$ & $\mathrm{NS}$ \\
Gly $(\mathrm{mmol} / \mathrm{l})^{*}$ & $\mathrm{NS}$ & $\mathrm{NS}$ & $\mathrm{NS}$ \\
$H b A_{l C}(\%)^{*}$ & $\mathrm{NS}$ & $\mathrm{NS}$ & $\mathrm{NS}$ \\
BMI $\left(\mathrm{kg} / \mathrm{m}^{2}\right)^{*}$ & $\mathrm{NS}$ & $\mathrm{NS}$ & $\mathrm{NS}$ \\
waist $(\mathrm{cm})^{*}$ & $\mathrm{NS}$ & $\mathrm{NS}$ & $\mathrm{NS}$ \\
\hline
\end{tabular}

* expressed as median (range)

\section{Visfatin}

Visfatin, in contrast to adiponectin and resistin, is an adipocytokine enzyme. In addition to its numerous functions, e.g. in the synthesis of nicotinamide adenine dinucleotide, maturation of vascular smooth muscle cells, inhibition of neutrophil apoptosis, etc., is involved in increasing insulin sensitivity through activation of insulin receptors (Samal et al. 1994). Serum levels of visfatin are increased in various chronic inflammatory diseases, e.g. rheumatoid arthritis or chronic inflammation of the intestinal mucosa such as ulcerative colitis or Crohn's disease (Moschen et al. 2007).

Caixàs et al. (2009), Han et al. (2012) and Guzel et al. (2013) described higher levels of visfatin in hypothyroidism (mainly patients with Hashimoto's thyroiditis), while after adjusting thyroid parameters with appropriate treatment, the levels of this enzyme were also adjusted (Caixas et al. 2009, Han et al. 2012, Guzel et al.
2013), in contrast to Ozkaya et al. (2009) who found unchanged levels of this adipocytokine in patients with hypothyroidism. According to Ozkaya et al. (2009) serum visfatin levels in euthyroid non-diabetic patients correlate positively with TSH. We did not prove this correlation (Table 6). However, levels of visfatin in euthyroid patients without thyroid disease or DM2 in $\mathrm{CG}$ correlated positively with $\mathrm{fT}_{4}$ levels which is in contrast to Farazandeh et al. (2011) and Yaylali et al. (2016). They did not prove any correlation between visfatin and thyroidal parameters in healthy individuals or in euthyroid patients with AIT (Farazandeh et al. 2011, Yaylali et al. 2016). There are controversies regarding the association of visfatin with overweight/obesity, DM2, insulin resistance, and metabolic syndrome. There is a direct association between plasma visfatin level and DM2. Visfatin binds to the insulin receptor at a site distinct from that of insulin and causes hypoglycaemia by 
reducing glucose release from liver cells and stimulating glucose utilization in adipocytes and myocytes (Adeghate 2008). We observed that visfatin negatively correlates with fasting glycaemia, however only in patients with AIT and without DM (Table 4). Early research suggested that visfatin produces insulin-mimetic effects by binding to the insulin receptors and activating downstream insulin signaling pathways (Fukuhara et al. 2005, Tilg and Moschen 2006, Tokunaga et al. 2008). However, due to failure to reproduce these data, Fukuhara and colleagues retracted their findings in 2007 (Fukuhara et al. 2007). The association between insulin resistance and blood visfatin concentrations is not clear. Some studies indicate that blood visfatin concentrations significantly correlate with insulin resistance or DM2 (Fukuhara et al. 2005, Chen et al. 2006, Dogru et al. 2007, Sandeep et al. 2007, Yilmaz et al. 2008), accordingly visfatin positively correlates with fasting glycaemia as we demonstrated in patients with AIT (Table 4). Other studies demonstrate that the association between diabetes and blood visfatin concentrations was not significant (Gunduz et al. 2011, Berndt et al. 2005, Krzyzanowska et al. 2006), thus visfatin did not correlate with $\mathrm{HbA}_{1 \mathrm{C}}$.

\section{Limitations}

Our study has several limitations:

- The main limitation is a relatively small number of patients in each of the studied disease population subgroups.

- There is a significant disbalance in gender between groups of patients and also between groups of patients and the CG. This disbalance may be important for resistin analyses as it tends to be higher in males.

- The age and other parameters are not normally distributed within particular groups.

- Age upper limit in each group was 65 years; this was due to the fact that older patients have higher probability of polymorbidity. But this limitation means that in our study adipokines (and other parameters) concentrations do not truly represent their distribution in the selected disease and general populations.

- $\quad$ This study has the exploratory nature.

\section{Conclusion}

The background of the association between DM2 and AIT is still not sufficiently clarified. Adipocytokines are unquestionably related to insulin sensitivity and resistance, and thus to DM2 as well as to TH. But how and whether these associations are related to each other is not yet known, so it is necessary to further investigating of them.

\section{Conflict of Interest}

There is no conflict of interest.

\section{Acknowledgements}

This study was supported by the Slovak Diabetes Society grant.

\section{References}

ADEGHATE E: Visfatin: structure, function and relation to diabetes mellitus and other dysfunctions. Curr Med Chem 15: 1851-1862, 2008. https://doi.org/10.2174/092986708785133004

AHIMA RS, QI Y, SINGHAL NS, JACKSON MB, SCHERER PE: Brain adipocytokine action and metabolic regulation. Diabetes 55: 145-154, 2006. https://doi.org/10.2337/db06-S018

ALTINOVA AE, TÖRÜNER FB, AKTÜRK M, BUKAN N, CAKIR N, AYVAZ G, ARSLAN M: Adiponectin levels and cardiovascular risk factors in hypothyroidism and hyperthyroidism. Clin Endocrinol 65: 530-535, 2006. https://doi.org/10.1111/j.1365-2265.2006.02628.x

BERNDT J, KLOTING N, KRALISCH S, KOVACS P, FASSHAUER M, SCHÖN MR, STUMVOLL1 M, BLÜHER M: Plasma visfatin concentrations and fat depot-specific mRNA expression in humans. Diabetes 54: 2911-2916, 2005. https://doi.org/10.2337/diabetes.54.10.2911

CABANELAS A, CORDEIRO A, DOS SANTOS ALMEIDA NA, MONTEIRO DE PAULA GS, COELHO VM, ORTIGA-CARVALHO TM, PAZOS-MOURA CC: Effect of triiodothyronine on adiponectin expression and leptin release by white adipose tissue of normal rats. Horm Metab Res 42: 254-260, 2010. https://doi.org/10.1055/s-0029-1246118. 
CAIXÀS A, TIRADO R, VENDRELL J, GALLART L, MEGÍA A, SIMÓN I, LLAURADÓ G, GONZÁLESCLEMENTE JM, GIMÉNEZ-PALO O: Plasma visfatin concentrations increase in both hyper and hypothyroid subjects after normalization of thyroid function and are not related to insulin resistance, anthropometric or inflammatory parameters. Clin Endocrinol (Oxf) 71: 733-738, 2009. https://doi.org/10.1111/j.13652265.2009.03546.X

CHEN MP, CHUNG FM, CHANG DM, TSAI JC-R, HUANG H-F, SHIN S-J, LEE Y-J: Elevated plasma level of visfatin/pre-B cell colony-enhancing factor in patients with type 2 diabetes mellitus. J Clin Endocrinol Metab. 91: 295-299, 2006. https://doi.org/10.1210/jc.2005-1475

CINAR N, GURLEK A: Association between novel adipocytokines adiponectin, vaspin, visfatin, and thyroid: An experimental and clinical update. Endocr Connect 2: 30-38, 2013. https://doi.org/10.1530/EC-13-0061

DOGRU T, SONMEZ A, TASCI I, BOZOGLU E, YILMAZ MI, GENC H, ERDEM G, GOK M, BINGOL N, KILIC S, OZGURTAS T, BINGOL S: Plasma visfatin levels in patients with newly diagnosed and untreated type 2 diabetes mellitus and impaired glucose tolerance. Diabetes Res Clin Pract 76: 24-29, 2007. https://doi.org/10.1016/j.diabres.2006.07.031

FARAZANDEH MM, SHABANI S, HOGHOOGHI RL, HEDAYATI M: Relationship between visfatin hormone and thyroid dysfunction in patients with hyperthyroidism and hypothyroidism. Kowsar Med J 16: 181-184, 2011.

FERNÁNDEZ-REAL JM, BOTAS-CERVERO P, LOPEZ-BERMANO A, CASAMITJANA R, FUNAHASHI T, DELGADO E, KIHARA S, RICART W: Adiponectin is independently associated with glycosylated haemoglobin. Eur J Endocrinol 150: 201-205, 2004. https://doi.org/10.1530/eje.0.1500201

FERNÁNDEZ-REAL JM, LÓPEZ-BERMEJO A, CASAMITJANA R, RICART W: Novel interactions of adiponectin with the endocrine system and inflammatory parameters. J Clin Endocrinol Metab 88: 2714-2718, 2003. https://doi.org/10.1210/jc.2002-021583

FUKUHARA A, MATSUDA M, NISHIZAWA M, SEGAWA K, TANAKA M, KISHIMOTO K, MATSUKI Y, MURAKAMI M, ICHISAKA T, MURAKAMI H, WATANABE E, TAKAGI T, AKIYOSHI M, OHTSUBO T, KAHARA S, YAMASHITA S, MAKISHIMA M, FUNAHASHI T, YAMANAKA S, HIRAMATSU R, MATSUZAWA Y, SHIMOMURA I: Visfatin: a protein secreted by visceral fat that mimics the effects of insulin. Science 307: 426-430, 2005. https://doi.org/10.1126/science.1097243

FUKUHARA A, MATSUDA M, NISHIZAWA M, SEGAWA K, TANAKA M, KISHIMOTO K, MATSUKI Y, MURAKAMI M, ICHISAKA T, MURAKAMI H, WATANABE E, TAKAGI T, AKIYOSHI M, OHTSUBO T, KIHARA S, YAMASHITA S, MAKISHIMA M, FUNAHASHI T, YAMANAKA S, HIRAMATSU R, MATSUZAWA Y, SHIMOMURA I: Erratum (Retracted article): visfatin: a protein secreted by visceral fat that mimics the effects of insulin. Science 318: 5850, article 565, 2007. https://doi.org/10.1126/science.318.5850.565b

GOODARZI MT, BABAAHMADI-RAZAEI H, KADKHODAEI-ELIADERANI M, HADDADINEZHAD S: Relationship of serum adiponectin with blood lipids, HbA1c, and hs-CRP in type II diabetic postmenopausal women. J Clin Lab Anal 21: 197-200, 2007. https://doi.org/10.1002/jcla.20175

GUNDUZ FO, YILDIMAK ST, TEMIZEL M, FAKI Y, CAKMAK M, DUMUSCAN M, SEZGIN F: Serum visfatin and fetuin-A levels and glycemic control in patients with obese type 2 diabetes mellitus. Diabetes Metab J 35: 523-528, 2011. https://doi.org/10.4093/dmj.2011.35.5.523

GUZEL S, SEVEN A, GUZEL EC, BUYUK B, CELEBI A, AYDEMIR B: Visfatin, leptin, and TNF- $\alpha$ : Interrelated adipokines in insulin-resistant clinical and subclinical hypothyroidism. Endocr Res 180: 183-193, 2013. https://doi.org/10.3109/07435800.2012.760588

HAN J, ZHAN T, XIAO W, CHANG C, AI H: Up-regulation of visfatin expression in subjects with hyperthyroidism and hypothyroidism is partially relevant to a nonlinear regulation mechanism between visfatin and tri-iodothyronine with various concentrations. Chin Med J 125: 874-881, 2012.

IGLESIAS P, DÍEZ JJ. Influence of thyroid dysfunction on serum concentrations of adipocytokines. Cytokine 40: 61-70, 2007. https://doi.org/10.1016/j.cyto.2007.10.001

IGLESIAS P, FIDALGO PA, CODOCEO R, DÍEZ JJ: Serum concentrations of adipocytokines in patients with hyperthyroidism and hypothyroidism before and after control of thyroid function. Clin Endocrinol (Oxf) 59: 621-629, 2003. https://doi.org/10.1046/j.1365-2265.2003.01897.x 
KAPLAN O, UZUM AK, ARAL H, UZUM G, VAHIT T, DEMIR O, PLANCI KN, KEZMEZACAR O, OZBEY NC: Unchanged serum adipokine concentrations in the setting of short-term thyroidectomy-induced hypothyroidism. Endocr Pract 18: 887-893, 2012. https://doi.org/10.4158/EP12001.OR

KRASSAS GE, PONTIKIDES N, LOUSTIS K, KOLIAKOS G, CONSTANTINIDIS T, KALTSAS T: Resistin levels are normal in hypothyroidism and remain unchanged after attainment of euthyroidism: relationship with insulin levels and anthropometric parameters. J Endocrinol Invest 29: 606-612, 2006. https://doi.org/10.1007/BF03344159

KRESSER C: The Role of Vitamin D Deficiency in Thyroid Disorders. (online, cited 2021 Feb 15). Available at: http://chriskresser.com/the-role-of-vitamin-d-deficiency-in-thyroid-disorders/

KRZYZANOWSKA K, KRUGLUGER W, MITTERMAYER F, RAHMAN R, HAIDER D, SHNAWA N, SCHEMTHANER G: Increased visfatin concentrations in women with gestational diabetes mellitus. Clin Sci (Lond) 110: 605-609, 2006. https://doi.org/10.1042/CS20050363

LINDSAY RS, FUNAHASHI T, HANSON RL, MATUSUZAWA Y, TANAKA S, TATARANNI PA, KNOWLER WC, KRAKOFF J: Adiponectin and development of type 2 diabetes in the Pima Indian population. Lancet 360: 57-58, 2002. https://doi.org/10.1016/S0140-6736(02)09335-2

MISRA A, VIKRAM NK: Clinical and pathophysiological consequences of abdominal adiposity and abdominal adipose tissue depots. Nutrition 19: 457-466, 2003. https://doi.org/10.1016/S0899-9007(02)01003-1

MOSCHEN AR, KASER A, ENRICH B, MOSHEIMER B, THEURL M, NIEDERGGER H, TILG H: Visfatin, an adipocytokine with proinflammatory and immunomodulating properties. J Immunol 178: 1748-1758, 2007. https://doi.org/10.4049/jimmunol.178.3.1748

MULLUR R, LIU Y-Y, BRENT GA: Thyroid hormone regulation of metabolism. Physiol Rev 94: 355-382, 2014. https://doi.org/10.1152/physrev.00030.2013

NOGUEIRAS R, GUALILLO O, CAMINOS JE, CASANUEVA FF, DIÉGUEZ C: Regulation of resistin by gonadal, thyroid hormone, and nutritional status. Obes Res 11: 408-414, 2003. https://doi.org/10.1038/oby.2003.55

OWECKI M, MICZKE A, PUPEK-MUSIALIK D, CYMERYS M, NIKISCH E, SOWIŃSKI J: Serum adiponectin concentrations are not related to glycosylated hemoglobin levels (HbAlc) in obese diabetic and non-diabetic caucasians. Exp Clin Endocrinol Diabetes 116: 173-177, 2008. https://doi.org/10.1055/s-2007-992116

OZKAYA M, SAHIN M, CAKAL E, SEZER K, KILINC M, SIMSEK IS: Visfatin plasma concentrations in patients with hyperthyroidism and hypothyroidism before and after control of thyroid function. J Endocrinol Investig 32: 435-439, 2009. https://doi.org/10.1007/BF03346482

SAMAL B, SUN Y, STEAMS G, XIE C, SUGGS S, MCNIECE I: Cloning and characterization of the cDNA encoding a novel human pre-B-cell colony-enhancing factor. Molecular Cell Biol 14: 1431-1437, 1994. https://doi.org/10.1128/MCB.14.2.1431

SANDEEP S, VELMURUGAN K, DEEPA R, MOHAN V: Serum visfatin in relation to visceral fat, obesity, and type 2 diabetes mellitus in Asian Indians. Metabolism 56: 565-570, 2007. https://doi.org/10.1016/j.metabol.2006.12.005

SANTINI F, MARSILI A, MAMMOLI C, VALERIANO R, SCARTABELLI G, PELOSINI C, GIANNETTI M, CENTONI R, VITTI P, PINCHERA A: Serum concentrations of adiponectin and leptin in patients with thyroid dysfunctions. J Endocrinol Invest 27: RC5-RC7, 2004. https://doi.org/10.1007/BF03346252

SIEMIŃSKA L, WOJCIECHOWSKA C, KOS-KUDŁA B, MAREK B, KAJDANIUK D, NOWAK M, GLOGOWSKA-SZELAG J, FOLTYN W, STRZELCZYK J: Serum concentrations of leptin, adiponectin, and interleukin-6 in postmenopausal women with Hashimoto's thyroiditis. Endokrynol Pol 61: 112-116, 2010.

SCHRONER Z, LAZÚROVÁ I, PETROVIČOVÁ J: Autoimmune thyroid diseases in patients with diabetes mellitus. Bratisl Lek Listy 109: 125-129, 2008.

SPRANGER J, KROKE A, MÖHLING M, BERGMANN MM, RISTOW M, BOEING H, PFEIFFER AFH: Adiponectin and protection against type 2 diabetes mellitus. Lancet 361: 226-228, 2003. https://doi.org/10.1016/S0140-6736(03)12255-6

STUMVOLL M, HÄRING H: Resistin and adiponectin - of mice and men. Obesity 10: 1197-1199, 2002. https://doi.org/10.1038/oby.2002.162 
TILG H, MOSCHEN AR: Adipocytokines: mediators linking adipose tissue, inflammation and immunity. Nat Rev Immunol 6: 772-783, 2006. https://doi.org/10.1038/nri1937

TOKUNAGA A, MIURA A, OKAUCHI Y, KATSUMORI S, FUKUHARA A, OKITA K, TAKAHASHI M, FUNAHASHI T, MIYAGAWA J-I, SHIMOMURA I, YAMAGATA K: The -1535 promoter variant of the visfatin gene is associated with serum triglyceride and HDL-cholesterol levels in Japanese subjects. Endocr J 55: 205-212, 2008. https://doi.org/10.1507/endocri.K07E-039

YAYLALI GF, TURGUT S, AKIN F, OZKAN S, TURAL M, ATA MT, OZLU C, ISLER K: Visfatin levels in subclinical hypothyroidism. Int J Pept Res Ther 22: 11-14, 2016. https://doi.org/10.1007/s10989-015-9479-3

YILMAZ MI, SAGLAM M, QURESHI AR, CARRERO JJ, CAGLAR K, EYILETEN T, SONMEZ A, CAKIR E, OGUZ Y, VURAL A, YENICESU M, STEINVINKEL P, LINDHOLM B, AXELSSON J: Endothelial dysfunction in type-2 diabetics with early diabetic nephropathy is associated with low circulating adiponectin. Nephrol Dial Transplant 23: 1621-1627, 2008. https://doi.org/10.1093/ndt/gfm828

YLDIZ BO, AKSOY DY, HARMANCI A, UNLUTURK U, CINAR N, ISILDAK M, USMAN A, BAYRAKTAR M: Effects of 1-thyroxine therapy on circulating leptin and adiponectin levels in subclinical hypothyroidism: a prospective study. Arch Med Res 44: 317-320, 2013. https://doi.org/10.1016/j.arcmed.2013.04.010

ZIORA KT, OSWIECIMSKA JM, SCHWIECHOTOWSKA E, OSTROWSKA Z, STOJEWSKA M, GORCZYCA P, ROJEWSKA K, ZIORA-JAKUTOWICZ K, SZCZEPANSKA M, ZIORA D: Assessment of serum levels resistin in girls with anorexia nervosa. Part II. Relationships between serum levels of resistin and thyroid, adrenal and gonadal hormones. Neuro Endocrinol Lett 32: 697-703, 2011. 